\title{
Making Room for China in the World Economy
}

\section{Citation}

Rodrik, Dani. 2010. Making Room for China in the World Economy. American Economic Review 100 (2): 89-93.

\section{Published Version}

http://dx.doi.org/10.1257/aer.100.2.89

\section{Permanent link}

http://nrs.harvard.edu/urn-3:HUL.InstRepos:5341587

\section{Terms of Use}

This article was downloaded from Harvard University's DASH repository, and is made available under the terms and conditions applicable to Open Access Policy Articles, as set forth at http:// nrs.harvard.edu/urn-3:HUL.InstRepos:dash.current.terms-of-use\#OAP

\section{Share Your Story}

The Harvard community has made this article openly available.

Please share how this access benefits you. Submit a story.

Accessibility 


\title{
MAKING ROOM FOR CHINA IN THE WORLD ECONOMY
}

\author{
Dani Rodrik \\ Harvard Kennedy School \\ Cambridge, MA 02138 \\ 6174959454 \\ Fax: 6174965747 \\ dani_rodrik@harvard.edu
}

December 2009

Paper prepared for the AEA session on "Growth in a Partially De-Globalized World," chaired and discussed by Philippe Aghion. 


\section{MAKING ROOM FOR CHINA IN THE WORLD ECONOMY}

\section{Dani Rodrik}

As it comes out of the crisis, the world economy faces two apparently conflicting demands. On the one hand, achieving global macroeconomic stability and preventing a protectionist backlash will require that we avoid large current account imbalances of the type that the world economy experienced in the run-up to the crisis. On the other hand, returning to rapid growth in the developing nations will require that they resume their conquest of global market share in tradable goods.

The challenge of meeting both demands is epitomized by the contentious U.S-China bilateral relationship. American (and European) policy makers blame China for an undervalued renminbi, which they argue is the root cause of China's huge trade surplus. Chinese leaders resist the pressure, fearing that appreciation will undercut the competitiveness of Chinese goods in world markets, hurt exports, and damage growth. The Western answer to this concern is that China needs to replace foreign demand with domestic demand as the engine of growth.

But if growth depends primarily on the supply of modern manufactured products and other tradables as opposed to services and non-tradables, as I will argue here, the Chinese position has more force than critics give it credit. The conventional fix for China’s current account surplus, consisting of a combination of expenditure expansion and currency appreciation, will shift the structure of the economy away from tradables and towards nontradables. This may be good for macroeconomic balance in China and elsewhere, but it will almost certainly have adverse effects on China’s growth—perhaps large enough to even endanger the country’s social and political stability.

\footnotetext{
* Parts of this paper draw heavily on Rodrik (2009). I thank Nicholas Lardy, Yingyi Qian, Anthony Saich, ShangJin Wei, Wing Thye Woo, and Martin Whyte for very helpful discussions on China.
} 
The good news is that there is no inherent conflict between China's growth and other countries’ desire to have reasonably balanced external accounts. What matters for growth in developing nations like China is not the size of their trade surplus, nor even the volume of their exports. What matters for growth is their output of non-traditional tradables, which can expand without limit as long as domestic demand (for those same goods) expands at the same time.

So there is a simple solution. It is possible to let the renminbi appreciate, and hence eliminate the trade surplus, as long as complementary policies are put in place to support modern tradables more directly. Such policies, combined with macroeconomic policies targeted at the current account, can achieve both external balance and structural change in favor of modern tradables. It is better to subsidize tradables directly than to subsidize them indirectly through the exchange rate which also happens to tax the domestic consumption of tradables.

There are many ways in which the profitability of tradables can be enhanced, including reducing the cost of non-traded inputs and services through appropriately targeted investments in infrastructure. But industrial policies, including explicit subsidies on tradables, are likely to be part of the arsenal as well (Rodrik 2008a, 2009). An important implication, therefore, is that the external policy environment will have to be more tolerant of such policies, as long as the effects on the trade balance are neutralized through appropriate adjustments in the real exchange rate. Permissiveness on industrial policies is the "price” to be paid for greater discipline on currency practices and external imbalances.

\section{Promote tradables if you want growth}

What is common in the experiences of Japan, South Korea, China, and all other growth superstars is that they based their growth strategies on developing industrial capabilities, rather 
than on specializing according to their prevailing comparative advantages. They each became manufacturing superpowers in short order—and much more rapidly than one would have expected based on their resource endowments. China’s export bundle was built up using strategic public investments and industrial policies that forced foreign companies to transfer technology, and as a result resembles one for a country that is three or four times as rich.

The lesson is this. High-growth countries are those that are able to undertake rapid structural transformation from low-productivity ("traditional”) to high-productivity (“modern”) activities. These modern activities are largely tradable products, and within tradables, they are mostly industrial ones (although tradable services are clearly becoming important as well). In other words, poor countries become rich by producing what rich countries produce.

Why is transition into modern industrial activities an engine of economic growth? As I discuss in Rodrik (2008b) and in line with a long tradition of dual-economy models, the answer is that there exist significant gaps between the social marginal productivities in traditional and modern parts of developing economies. Even vey poor economies have economic activitieshorticulture in Ethiopia, auto assembly in India, consumer electronics in China—where productivity levels are not too far off from what we observe in the advanced economies. As resources move from traditional activities towards these, economy-wide productivity increases.

These gaps can be due to a wide range of features that are specific to under-development. I discuss two broad categories in Rodrik (2008b). One has to do with institutional weaknessessuch as poor protection of property rights and weak contract enforcement—which make themselves felt more intensively in tradable activities. The second relates to various market failures and externalities—e.g., learning spillovers and coordination failures—associated with modern activities. In both cases, industrial activity and investment are underprovided in market 
equilibrium. Anything that speeds up structural transformation in their direction will speed up the rate of economic growth.

Even though actual policies have differed significantly across successful countries, one can still identify some important common elements. First, it is clear that sound "fundamentals" have played a role, as long as we interpret the term quite broadly and not associate it with any specific laundry list of policies (such as the Washington Consensus or the governance reforms that are in fashion currently). Second, all successful countries have followed what one might call "productivist” policies. These are activist policies aimed at enhancing the profitability of modern industrial activities and accelerating the movement of resources towards modern industrial activities. They go considerably beyond the conventional recommendation to reduce red tape, corruption, and the cost of doing business. They entail in addition (or sometimes instead): explicit industrial policies in support of new economic activities (trade protection, subsidies, tax and credit incentives, special government attention); undervalued currencies to promote tradables; and a certain degree of repression of finance, to enable subsidized credit, development banking, and currency undervaluation.

It is true that industrial policies have often failed. But it is also true that it is virtually impossible to identify countries, whether in Asia (South Korea, Taiwan) or in Latin America (Chile), that have done well without them. Just as it is the case with fiscal policy, say, or education policy, what distinguishes good performers from bad performers is not the presence or absence of the policy, but the skill with which it has been implemented.

The reason that undervaluation of the currency works as a powerful force for economic growth is that it acts as a kind of industrial policy. By raising the domestic relative price of tradable economic activities, it increases the profitability of such activities, and spurs capacity 
and employment generation in the modern industrial sectors that are key to growth. As discussed in detail in Rodrik (2008b), the association between undervalued currencies and high growth is a very robust feature of the post-war data, particularly for lower-income countries.

Undervaluation has the practical advantage, compared to explicit industrial policies, of being an across-the-board policy not requiring selectivity and therefore entailing fewer agency problems (rent-seeking and corruption). Perhaps this accounts for its widespread success in promoting development. But it also has several disadvantages. Most important in the present context, it acts also as a domestic tax on the consumption of tradables (as it raises the relative price of imported goods). That is why it produces an excess supply of tradables-a trade surplus. The last point is of special relevance to the case of China.

\section{China and currency undervaluation}

China has not always had a large external imbalance, or an undervalued currency. In fact, prior to the present decade it never had a current account surplus exceeding 4 percent (of GDP). After having jumped to nearly that level in 1997 during the Asian financial crisis, its surplus steadily fell until 2001, which is the year when things turned around. From 2001 on, China's surplus began its inexorable rise to more than 10 percent by 2007. The index of undervaluation I used in Rodrik (2008b) similarly bottoms out in 2001 and increases thereafter. Interestingly, 2001 also saw China joining the World Trade Organization, after years of negotiation. Is it a coincidence that China's current account imbalance began to widen and its currency undervaluation started to rise just as the country became a member of the trade body?

Perhaps not. WTO membership made it difficult, if not impossible, for China to promote its industries with the type of explicit industrial policies that the country had been relying on. 
Prior to the late 1990s, China's manufacturing industries were promoted by a wide variety of inducements, including high tariff barriers, investment incentives, export subsidies, and domestic content requirements on foreign firms. As a condition of membership, China had to phase out these policies. From levels that were among the highest in the world as late as the early 1990s China's import tariffs fell to single-digit levels by the end of the decade. Local content requirements and export subsidies were eliminated. Currency undervaluation, or protection through the exchange rate, became the de facto substitute.

If undervaluation has supported China's recent growth, what kind of growth penalty would the economy suffer if China were to let its currency appreciate (in the absence of compensating changes in industrial policies)? In Rodrik (2008b), I report panel regressions which suggest that the partial correlation between my index of (log) undervaluation and annual growth rate is 0.026 for developing nations. (For reasons explained in that paper, I am inclined to think of this relationship as causal.) However, in the case of China this estimate rises to 0.086, a much bigger number that may be due to the large reservoir of surplus labor and the huge gap in the productivity levels of modern and traditional parts of the economy. This estimate implies that a 10 percent appreciation would reduce China’s growth by 0.86 percentage points.

By many accounts, including my own estimates (based on price-level comparisons with adjustments for Balassa-Samuelson effects), China's currency is undervalued by around 25 percent. Correcting this undervaluation would result in a reduction in Chinese growth of 2.15 percentage points per annum $(=0.25 \times 0.086)$. This is a sizable effect, even by the standards of China's superlative growth record. Most importantly, a slowdown of this magnitude would put China below the 8 percent growth threshold its leadership apparently believes is necessary to maintain social peace and avert social strife. 
No-one knows where the 8 percent figure really comes from; it clearly does not have a scientific basis. Many China experts think the Chinese society and polity are capable of handling growth much lower than that. Nevertheless, even if the political implications can be put aside, it would be hardly a desirable outcome if the most potent poverty-reduction engine the world has ever known were to experience a noticeable slow down. It is true that other countries that relied on exports to grow rapidly—such as Germany, Japan, and South Korea—eventually had to let their currencies appreciate. But China is still a very poor country, at barely above one-tenth the income level of the U.S. It has a huge reservoir of surplus labor in the countryside. In addition, it has to live with restrictions on its industrial policies that none of these other countries, in preWTO days, had to abide by.

\section{Is the key the trade surplus, exports, or the production of tradables?}

The real exchange rate affects the trade balance, the supply of exports, and the production of tradables. Which of these is the channel through which an undervaluation spurs growth?

Consider the difference between the "exports" and "tradables” stories. For export quantitites to matter for growth over the longer term, one must believe either in learning or other spillovers from exports, which have been hard to document, or in the explanation I sketched out above, in which tradables are special because that is where the higher productivity activities are found. The two accounts differ on the importance they attach to the act of exporting per se. The "spillovers-from-exporting” story relies on the technological or marketing externalities that are created when a tradable good crosses an international boundary. The "tradables-are-special" story is indifferent to whether international trade actually takes place or not. 
In Rodrik (2009) I ran a series of horse races between these contending mechanisms. I estimated growth regressions with fixed effects for countries and time periods, using a panel of five-year subperiods. The regressors, in addition to the fixed effects, were lagged income (to account for convergence), the share of industrial value added in GDP, the share of exports in GDP, and the trade surplus as a percent of GDP.

When industry and export shares are included together, both are statistically significant, but the estimated impact of industrial activity is more than twice as powerful. A one standarddeviation increase in industrial shares is estimated to increase growth by 1.6 percentage points, while the corresponding increase in export shares boosts growth only by 0.7 percentage points. Moreover, it turns out that the result with export shares is not robust. When the sample is restricted to post-1990 data or a few observations corresponding to countries with very high export shares (e.g., Luxemburg and Hong Kong) are excluded, the estimated coefficient on exports becomes insignificant. Perhaps most importantly, when we restrict the sample to developing countries, the coefficient on the export share turns slightly negative (and is statistically insignificant), while the coefficient on the industry share rises and remains strongly significant. The horse race between industrial activity and export orientation has a clear winner.

The horse race between industry shares and trade surpluses also produces a clear winner. Once industry shares in GDP are controlled for, trade surpluses exert no additional positive effect on economic growth. This is true for the full sample, for post-1990 data, for samples in which large trade deficits or surpluses have been removed, and for samples restricted to developing countries. In each one of these runs, the industry variable is highly significant while the trade surplus is not. 
The implication for China and developing nations that have gotten hooked on trade surpluses or exports as their "engines of growth" is clear: what really matters is the output of tradables (here proxied by industrial production). Neither exports nor trade surpluses are key as long as domestic demand for tradables can be increased alongside the domestic supply.

\section{Structural change and growth without trade surpluses}

Let us return to the interpretation underlying the growth dynamics that I sketched out above. In this perspective poor countries are poor because too few of their resources are in modern, high productivity activities. Fast growth happens when there is rapid structural transformation from low-productivity traditional sectors to high-productivity modern activities. The reason this transformation is not an automatic, market-led process is that there are severe market or institutional failures whose costs are borne disproportionately by the modern sectors. Sometimes transformation is blocked because of low domestic saving and high cost of capital, which keep investment and structural change sluggish. But more typically the problem is a large wedge between private and social returns in modern sectors. These sectors are subject both to learning spillovers and coordination failures and to high costs imposed by weaknesses in legal and regulatory institutions. These weaknesses are hard to remove in short order, and the experience of advanced economies is that they are addressed only through the long course of decades, if not centuries.

So while it would be desirable to address these shortcomings directly, by removing market failures and fixing institutions, as a practical matter such an agenda is too broad and ambitious and hence too unrealistic. As noted previously, successful countries have pursued growth strategies that alleviate these constraints indirectly, by raising the relative profitability of 
modern activities through other means. What all these strategies have in common is that they act as subsidies on tradables.

Once we strip these strategies to their essence, it becomes easier to understand what is central and what is incidental to their working. In particular, we can see that a strategy of subsidizing tradables need not be associated with undervalued exchange rates and trade surpluses. It is possible to enhance production incentives for tradables, and do so by as wide a margin as is necessary, without creating spillovers to the rest of the world in terms of trade imbalances. Unlike currency undervaluation, which taxes domestic consumption of tradables, a policy of explicitly subsidizing tradables (combined with macroeconomic policies that maintain external balance) boosts the domestic consumption of tradables.

What form should this subsidy take in practice? As discussed in Rodrik (2009), there are three broad approaches: (a) industrial policies; (ii) reducing input costs for tradables; and (iii) incomes policies. All of these pose practical policies in implementation, so the appropriate mix depends on the circumstances of each country.

In principle, industrial policy is ideally suited to the problem at hand. What needs to be done is to enhance the relative profitability of non-traditional products that face large information externalities or coordination failures, or which suffer particularly strongly from the poor institutional environment. That is what good industrial policy attempts to do. Tax exemptions, directed credit, payroll subsidies, investment subsidies, export processing zones are some of the forms in which industrial policy gets implemented. What is distinctive about these policies is that they target specific firms or sectors, and therefore privilege some at the expense of others. That is what makes industrial policy controversial of course. But as long as the targeting is done broadly well—as long as it focuses on new activities at the outer margins of a 
country's underlying competence- - the potential upside is large. The advantage of industrial policy relative to currency undervaluation is precisely that it allows greater fine tuning and discrimination: traditional tradables (such as primary products and industrial products in which a country has already established itself) need not be subsidized, and the consumption of tradables need not be taxed.

There is still a sense in which subsidies on modern tradables can spill across borders. Even if the net supply of tradables does not increase in aggregate, the net supply of those that are targeted for promotion will. Other countries will be in the receiving end of this, and if they remain passive, their own industrialization incentives will be blunted. But the right way of expressing this problem is to say that the use of "optimal" industrial policies in some countries increases the costs of not using such policies in others. As some countries alleviate their market imperfections, the costs of not dealing with these imperfections get exacerbated elsewhere. So as long as all countries are following industrial policies that are optimal from their perspective, there are no spillovers to contend with. The spillovers in question can be effectively neutralized as long as other (developing) countries are following appropriate industrial policies as well.

The main external obstacle to the wider use of industrial policies by the larger developing countries is the WTO's Agreement on Subsidies. This Agreement prohibits the use of subsidies which take the form of fiscal expenditures conditioned on export performance. More seriously, it also renders "actionable" the use of subsidies that have the effect of increasing exports, even if they are not directly conditioned on exports. (Least developed countries are exempt from these rules.) A literal application of this standard would rule of many kinds of industrial policies, the objective of which is precisely to increase the domestic supply of tradables. 
In a world where economic growth requires the encouragement of modern economic activities in developing nations, the Agreement on Subsidies makes little economic sense. It rules out a desirable second-best policy for promoting economic diversification and structural change. It has the unintended consequence of inducing governments to favor an inferior policy (in view of its spillovers into trade imbalances), namely undervalued currencies. Worse still, it may encourage trade protection as a defensive measure against industrial imports. If we want greater international oversight on currency practices, as I think we should, we will need to substantially relax discipline over industrial subsidies.

\section{REFERENCES}

Rodrik, Dani, “Normalizing Industrial Policy,” Commission on Growth and Development Working Paper No. 3, Washington, DC, 2008. (2008a)

Rodrik, Dani, “The Real Exchange Rate and Economic Growth,” Brookings Papers on Economic Activity, 2008:2. (2008b)

Rodrik, Dani, “Growth after the Crisis,” unpublished paper, Harvard Kennedy School, September 2009, http://www.hks.harvard.edu/fs/drodrik/Growth\%20after\%20the\%20crisis.pdf. 